\title{
RISK AND COST OF SOVEREIGN DEBT IN THE MEMBER STATES OF THE EUROPEAN UNION AS A FACTOR OF THEIR ECONOMY DEVELOPMENT
}

The financing cost per unit of sovereign debt shows a significant difference in individual EU member-states. This article tries to find an explanation for this. As one of the reasons, it explores the phenomenon that in the wake of the financial crisis sovereign risk has become a factor seriously affecting interest rates both in the Euro-zone countries and the countries having their own currencies. The average interest cost is also affected by the choice of the countries to give priority to either cost or risk minimisation in their sovereign debt management strategies.

Keywords: risk, management, sovereign debt, currency, cost minimization.

DOI: 10.21272/mmi.2018.4-23

Problem statement. The global financial crisis of 2008-2009 brought the problem of severe indebtedness of several EU member states to the surface. The general opinion according to which state bankruptcy may only threaten developing countries, while developed countries will always be able to repay their debts on time, was proven wrong. Indebted countries were not only threatened by state bankruptcy but the significant rise in interest rates also made the financing of sovereign debt more expensive. Since then interest rates have dropped to a record low level, which has also lowered the cost of indebtedness. Risks related to sovereign debthave dropped on the short term. The debt to GDP ratio however significanty increased in several EU member states between 2007 and 2016, which projects the danger that sovereign debtfinancing may again become a problem in severely indebted EU member states once the abundance of money typical of global markets for many years now ends. Therefore, it is reasonable to take some time during this period of peace to analyse the trends of financing the cost of sovereign debt and its key factors also through international comparisons.

Analysis of recent researches and publications. Using the data ofEU member states, we are first searching for an answer to the question of what correlation exists between the level of sovereign (country) risk and the average cost of financing the sovereign debt (measured by the interest payable per unit of general government gross debt). Thereafter, we will examine the extent to which the differences between the costs of financing can be explained by the differences in the debt management strategies of individual countries. Before we start discussing this, let us review the trends in sovereign debt ratios and interest coverage ratios in the examined countries between 2007 and 2016.

The data of Table 1 show trends of general government gross debt as a percentage of gross domestic product (sovereign debt ratio) and cost of interest as a percentage of general government gross debt (interest coverage ratio) in EU member states in 2007 (in the year before the global financial crisis), 2011, 2014 and 2016. The data reflect serious differences both in time and among the different countries. At the same time, general trends are also noticeable in the case of both ratios. As far as the sovereign debtratio is concerned, ithad clearly shown a significant increase with the exception of just a few countries from 2007 to 2011, and this growth had been continuous albeit slower up until 2014 with the exception of six countries. The picture was already more favourable between 2014 and 2016 as more than half of the EU member states could mitigate their indebtedness if only to a small extentduring that period. As the result of the described partial processes, the sovereign debt ratio of each EU member state - except for Malta - was over the 2007 level to quite a large extent in most of the member states in 2016 (see Fig. 1). 
Розділ 4 Проблеми управління інноваційним розвитком

Table 1- General government gross debt as a percentage of gross domestic product (GDP) and cost of interest as a percentage of general government gross debt (2007-2016) [13]

\begin{tabular}{|c|c|c|c|c|c|c|c|c|c|}
\hline \multirow{2}{*}{ Country } & \multirow{2}{*}{ Abs. } & \multicolumn{4}{|c|}{ Public debt/ GDP } & \multicolumn{4}{|c|}{ Cost of interest/public debt } \\
\hline & & 2007 & 2011 & 2014 & 2016 & 2007 & 2011 & 2014 & 2016 \\
\hline Belgium & (BE) & 87,00 & 102,60 & 106,70 & 105,90 & 4,60 & 3,51 & 3,09 & 2,74 \\
\hline Bulgaria & (BG) & 16,30 & 15,20 & 27,00 & 29,50 & 6,75 & 4,61 & 3,33 & 2,71 \\
\hline Czech Republic & (CZ) & 27,80 & 39,80 & 42,20 & 37,20 & 3,96 & 3,27 & 3,08 & 2,42 \\
\hline Denmark & (DK) & 27,30 & 46,10 & 44,00 & 37,80 & 5,86 & 4,34 & 3,41 & 3,44 \\
\hline Germany & $(\mathrm{DE})$ & 63,70 & 78,70 & 74,90 & 68,30 & 4,24 & 3,18 & 2,40 & 2,05 \\
\hline Estonia & (EE) & 3,70 & 6,10 & 10,70 & 9,50 & 5,41 & 1,64 & 0,93 & 1,05 \\
\hline Ireland & $(\mathrm{IE})$ & 23,90 & 109,60 & 105,30 & 75,40 & 4,18 & 3,01 & 3,70 & 3,05 \\
\hline Greece & (EL) & 103,10 & 172,10 & 179,70 & 179,00 & 4,36 & 4,24 & 2,23 & 1,79 \\
\hline Spain & (ES) & 35,60 & 69,50 & 100,40 & 99,40 & 4,49 & 3,60 & 3,49 & 2,82 \\
\hline France & (FR) & 64,30 & 85,20 & 94,90 & 96,00 & 4,04 & 3,05 & 2,32 & 1,98 \\
\hline Croatia & (HR) & 37,70 & 65,20 & 86,60 & 84,20 & 5,04 & 4,60 & 4,04 & 3,92 \\
\hline Italy & (IT) & 99,80 & 116,50 & 131,80 & 132,60 & 4,81 & 4,03 & 3,49 & 3,02 \\
\hline Cyprus & (CY) & 53,50 & 65,20 & 107,10 & 107,80 & 5,23 & 3,37 & 2,61 & 2,41 \\
\hline Latvia & (LV) & 8,40 & 42,70 & 40,90 & 40,10 & 4,76 & 4,22 & 3,42 & 2,74 \\
\hline Lithuania & (LT) & 15,90 & 37,20 & 40,50 & 40,20 & 4,40 & 4,84 & 3,95 & 3,48 \\
\hline Luxembourg & (LU) & 7,80 & 18,80 & 22,40 & 20,00 & 3,85 & 2,66 & 1,79 & 1,50 \\
\hline Hungary & (HU) & 65,60 & 80,70 & 75,70 & 74,10 & 6,25 & 5,20 & 5,28 & 4,32 \\
\hline Malta & (MT) & 62,40 & 70,40 & 64,30 & 58,30 & 5,61 & 4,55 & 4,20 & 3,77 \\
\hline Netherlands & $(\mathrm{NL})$ & 42,70 & 61,60 & 67,90 & 62,30 & 4,68 & 2,92 & 2,06 & 1,77 \\
\hline Austria & (AT) & 65,10 & 82,60 & 84,40 & 84,60 & 4,92 & 3,39 & 2,96 & 2,48 \\
\hline Poland & $(\mathrm{PL})$ & 44,20 & 54,10 & 50,20 & 54,40 & 4,98 & 4,62 & 3,78 & 3,13 \\
\hline Portugal & (PT) & 68,40 & 111,40 & 130,60 & 130,40 & 4,24 & 3,86 & 3,75 & 3,22 \\
\hline Romania & (RO) & 12,70 & 34,20 & 39,40 & 37,60 & 5,51 & 4,68 & 4,06 & 3,99 \\
\hline Slovenia & (SI) & 22,80 & 46,60 & 80,90 & 79,70 & 5,26 & 4,08 & 4,08 & 4,02 \\
\hline Slovakia & (SK) & 30,10 & 43,70 & 53,60 & 51,90 & 4,65 & 3,43 & 3,54 & 3,28 \\
\hline Finland & $(\mathrm{FI})$ & 34,00 & 48,50 & 60,20 & 63,60 & 4,12 & 2,89 & 1,99 & 1,73 \\
\hline Sweden & (SE) & 39,00 & 37,50 & 45,20 & 41,60 & 4,36 & 3,20 & 1,55 & 0,96 \\
\hline United Kingdom & (UK) & 42,00 & 81,60 & 88,10 & 89,30 & 5,24 & 3,92 & 3,06 & 2,80 \\
\hline
\end{tabular}

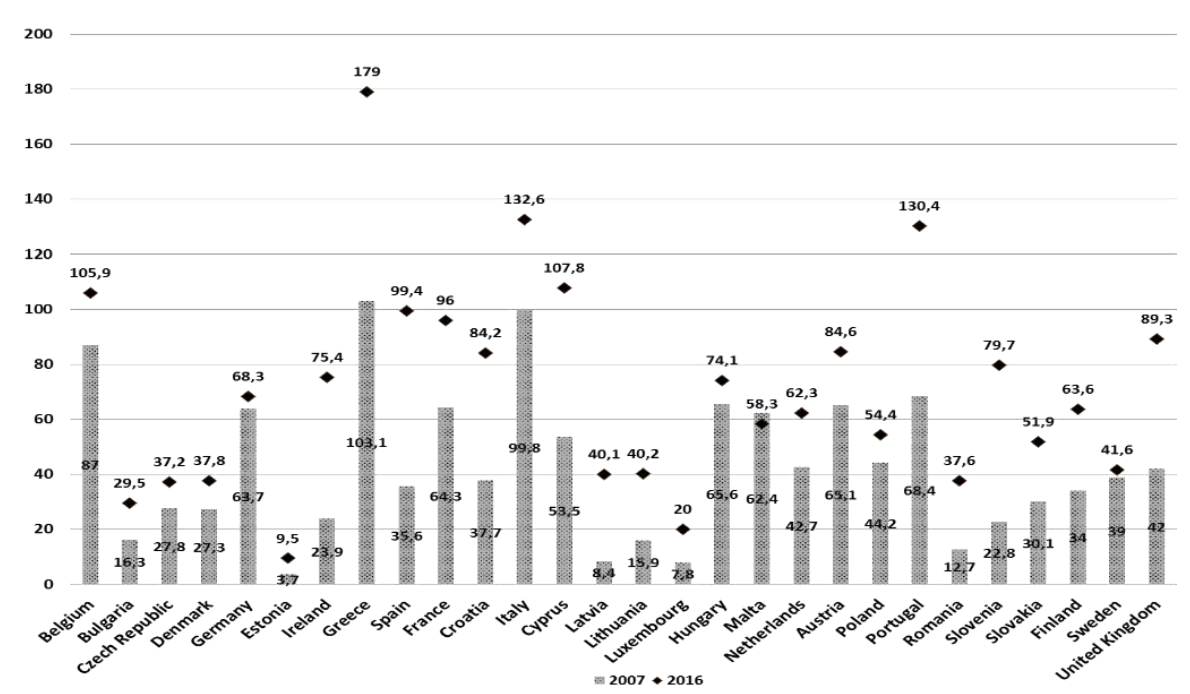

Figure 1 - General government gross debt as a percentage of gross domestic product in EU member states in 2007 and in 2016 [13] 
Г.3. Пулай. Ризик витрат на суверенний борг у державах-членах Європейського союзу як фактор розвитку їхньої економіки

The trend is clear in the case of the interest coverage ratio: by 2011 interest costs had dropped to the pre-crisis level, and they have been continuously dropping ever since (see Table 1). The rate of this drop however has been different in each country. The highest and lowest rate of the interest coverage ratio was 1.75 in 2007, 3.17 in 2011, 5.68 in 2014 and 4.50 in 2016.

The increase in the differences between 2007 and 2014 can be mostly explained by the slow pace with which the countries with higher sovereign debt ratio were able to renew the financing of their sovereign debt portfolio, i.e. to swap their high-yield government bonds for lower yield bonds. This is clearly demonstrated for instance by the fact that Estonia, which had had the lowest sovereign debt ratio in 2007, reduced its interest coverage ratio to one sixths between 2007 and 2014, while Italy which had had the highest sovereign debt ratio in 2007 among member states financed on a market basis, could only reach a 27 percent drop. The Italian indicator improved by a further 16 percent between 2014 and 2016, while Estonia could not reduce its interest coverage ratio any more.

We have inserted a chart with the changes of the interest coverage ratio between 2007 and 2016 (Figure 2) to better illustrate the trends of the interest coverage ratio of the different countries.

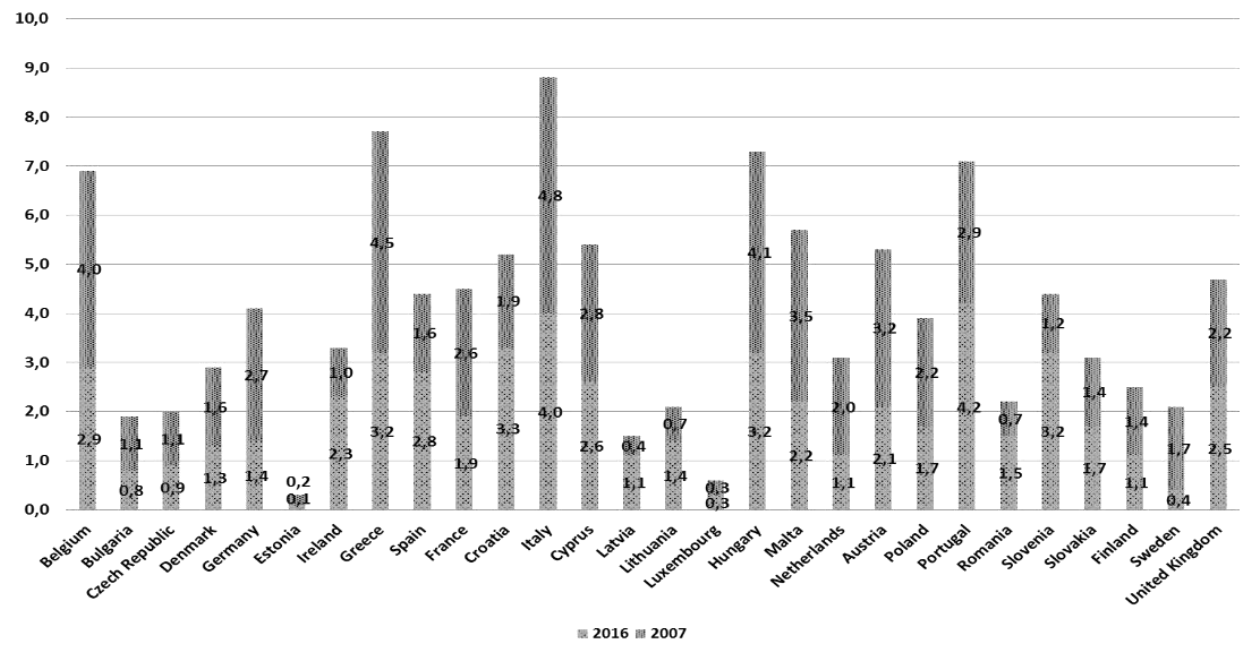

Figure 2 - Cost of interest as a percentage of general government gross debt in EU member states in 2007 and in 2016 [13]

The Figure 2 shows clearly that the extent of the drop of the interest coverage ratio in this period was significantly different between various countries, which indicated that the different countries could use the average drop in interest costs to varying extent to mitigate the interest costs of their indebtedness.

Selection of the unsolved questions. The financing cost per unit of sovereign debt shows a significant difference in individual EU member-states. This article tries to find an explanation for this. As one of the reasons, it explores the phenomenon that in the wake of the financial crisis sovereign risk has become a factor seriously affecting interest rates both in the Euro-zone countries and in the countries having their own currencies. The average interest cost is also affected by the choice of the countries to give priority to either cost or risk minimisation in their sovereign debt management strategies.

The main purpose of the article is to develop methodological provisions and practical recommendations for assessing the value of sovereign debt in the member states of the European Union. The level of sovereign risk, which after the financial crisis began to seriously affect interest rates both in the euro area countries, and in countries that have their own currencies, is considered in detail. 
Research findings. According to the general philosophy of finances, there is a strong correlation between the risk and the interest cost of individual deals, i.e. - if all other factors are constant - the higher the risk of a deal, the higher its interest rate. The credit deals financing sovereign debt carry differentinherentrisks. Such is sovereign risk or country risk, i.e. the danger that the borrowing state will notbe able to repay the credit. This risk remains at a minimum level under normal conditions, but in the case of countries deeply sunk in debt and having severe misbalances this is also a possible alternative. So much so that even insurance may be taken out for this type of risk. The middle market rate of insurance swap deals concluded for the risk of government bonds becoming defaulted is called CDS (credit default swap) ratio. The CDS ratio is measured in basis points, which are a percentage point multiplied by one hundred (e.g. $0.5 \%=50$ basis points). CDS depends on the credit (repayment) risk rating of a country. This is why itcan grasp the level of sovereign (country) risk. We are doing the same and measuring sovereign risk with CDS. Effectively, CDS is a spread, which should actually be paid if the lender (the purchaser of the bond) managed the repayment risk with insurance. But this is usually solved differenty in the general practice, and the higher risk is managed by the lender itself in such a way that it will only purchase the bonds of a state which is considered risky if the interest rate is also higher. Consequently, we may assume a strong positive correlation between the CDS and the interest coverage ratio. This correlation however is notdeterministic as CDS only reflects the risk of the repayment of the bond, and it does not reflectany other risks that may arise during the disbursement of the debt, like renewal, interest or exchange rate risks. Their management also incurs costs, which are built into the costs of debt financing. These costs depend on several other factors as well, for instance the variety of maturities, currencies and bondholders (retail or financial investors) of the financial assets funding the debt. Hence, it is a legitimate question, how the level of sovereign debt affects the average cost of sovereign debt financing. This is also a valid question because it is exactly sovereign risk which can be mostinfluenced by the economic policy of a given member state by harnessing sovereign debt, creating economic balance and therefore driving sovereign risk down to a minimum level. The reverse of this is also true, i.e. bad economic policy increases the level of sovereign risk, and therefore also the costs of funding sovereign debt, which further exacerbates indebtedness and lack of balance. This is the practical significance of the theoretical foundation of our analysis.

We are using a mathematical-statistical method in our analysis to find a correlation between sovereign risk indicated by CDS and the average cost of sovereign debt. For the purposes of our analysis, sovereign risk was considered an independent $(X)$ variable and the gross interest cost per unit of sovereign debt to be a dependent $(Y)$ variable. We made the analysis separately for countries belonging to the Euro-zone, and for countries having their own currencies because in the former case there was also the effect of the country risk mitigating or increasing the risk related to membership in the Euro-zone. (The regression test did not include Cyprus and Greece, members of the Euro-zone because loans disbursed by the IMF and the European Union with an end to avoid state bankruptcy play an important role in their debt financing. The interest rates of these loans are much more favourable than the interest level of the state securities market, which would significantly distort the analysis).

We fitted a regression curve to the data points to make the correlation of the variables quantifiable. We selected the regression function, which gave the best fit to the series of data points based on the maximum value of $R^{2}$, i.e. the coefficient of determination. The value (between 0 and 1 ) of the coefficient of determination showed the strength of the correlation between the variables, through which it showed the correctness of the fit of the regression function to the values; the higher the value of the coefficient of determination, the better the fit. We also carried out the analysis with the data of 2007, 2014 and 2016, primarily to demonstrate how much the correlation between sovereign risk and the average interest cost of sovereign de bt was affected by the increase of sovereign risks due to the global financial crisis and later by the general drop in interest rates.

The coefficient of determination $\left(R^{2}\right)$ calculated on the basis of 2007 data gave the best fit in case of a linear function, however it did not indicate strong correlation either. $R^{2}=0.24$ in the case of the Eurozone, while $\mathrm{R}^{2}=0.31$ in the case of the countries using their own national currencies. If the data are 
Г.3. Пулай. Ризик витрат на суверенний борг у державах-членах Європейського союзу як фактор розвитку їхньої економіки

inserted in a linear function, we get the following parameters for the two functions: Euro-zone (2007):

$Y_{\mathrm{E} 07}=0.0315 X+4.2305$. Countries using their national currencies $(2007): Y_{\mathrm{N} 07}=0.0298 X+4.4468$.

We will show the resulting linear curves in figures 3 and 4.

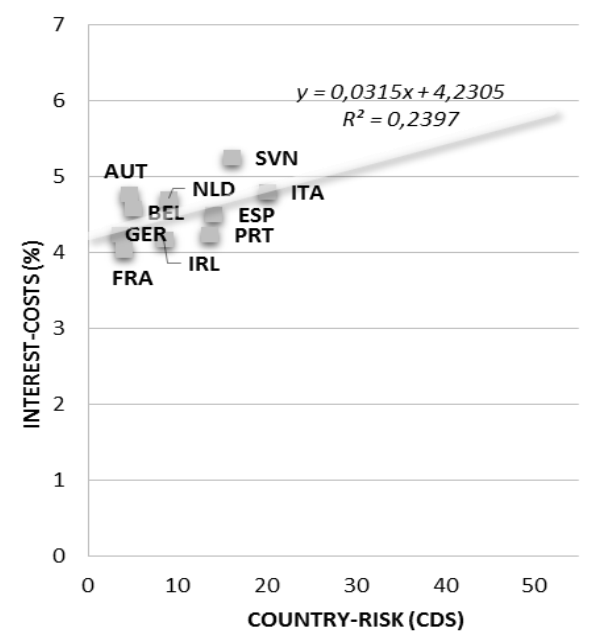

Figure 3 - Correlation between country (sovereign) and interest coverage in Euro-zone member states in 2007 (built by the author based on [11, 13])

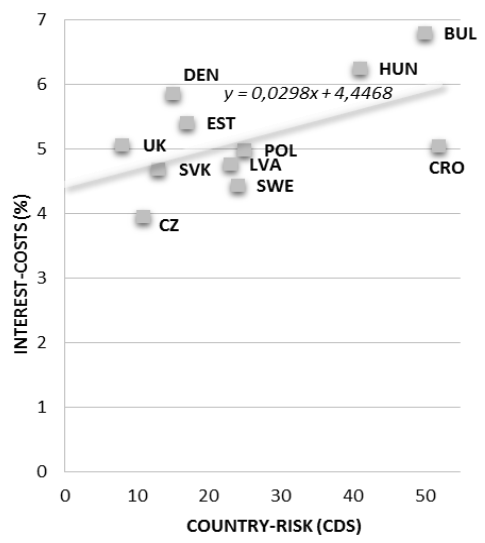

Figure 4 - Correlation between country (sovereign) and interest coverage in EU member states with national currency in 2007 (built by the author based on [11, 13])

The function shows that the interest rate started out from 4.2305 percent in the Euro-zone, but its trajectory was not steep at all: a one-notch increase of the CDS only brought about a 0.03 unit increase in the growth of average interest cost. The situation was the same in countries using their national currencies. Their interestrate started out from a somewhat higher level (4.4468\%), and it increased even more slowly: a one-notch increase in the CDS spread was only followed by a 0.0298 unit increase in the average interest cost. All this also reinforces the contents of the introduction, that financiers simply ignored the risk of state bankruptcy. Consequently, sovereign risk only had a minimum effect on interest costs. 
Going beyond the turbulences of the years of the crisis and the directly following years, we examined the correlation between sovereign risk and the average financing of sovereign debt based on the 2014 data. The coefficient of determination calculated based on 2014 data gave the best fit in the case of the logarithmic function, and indicated a much stronger correlation compared to 2007. $R^{2}=0.66$ in the case of the Euro-zone, while $R^{2}=0.56$ in the case of the countries using their national currencies. Having inserted the data in the logarithmic function, we got the regression functions with the following parameters: Euro-zone (2014): $Y_{E 14}=$ $0.6747 \ln (X)+0.2429$. Countries using their national currencies $(2014): Y_{N 14}=0,7101 \ln (x)+0,5129$. (The parameters of the functions calculated based on 2007 and 2014 data cannotbe directly compared because different type functions gave the best fit in the two years.) The functions are shown in figures 5 and 6 .

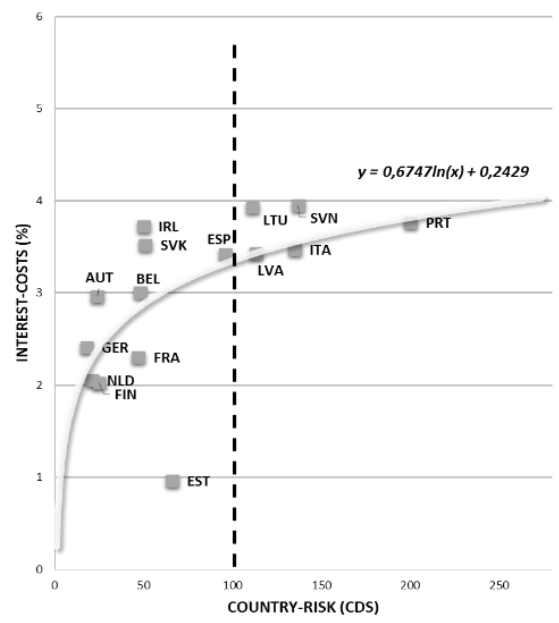

Figure 5 - Correlation between country (sovereign) and interest coverage in Euro-zone member states in 2014 (built by the author based on [12, 13])

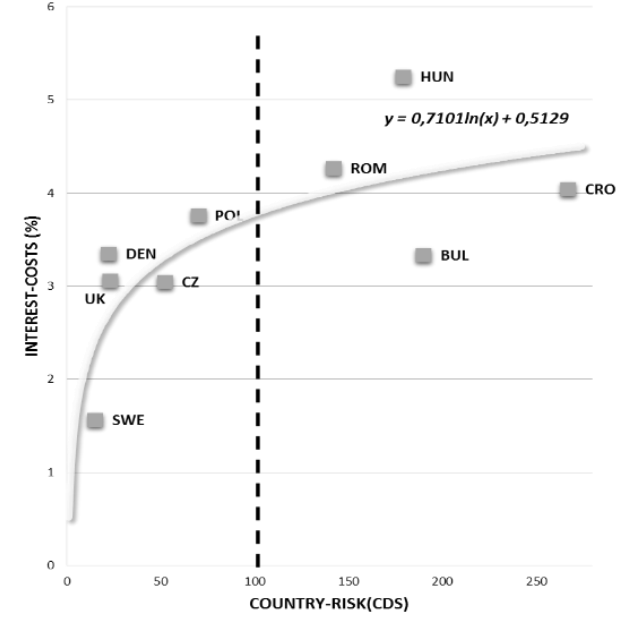

Figure 6 - Correlation between country (sovereign) and interest coverage in EU member states with national currency in 2014 (built by the author based on [12, 13]) 
Г.3. Пулай. Ризик витрат на суверенний борг у державах-членах Європейського союзу як фактор розвитку їхньої економіки

The parameters of steepness in the case of both functions indicate that sovereign risk played an important role in the interest cost trend of sovereign debt in 2014. This effect was stronger (0.7101) in the countries using their own national currencies than in the Euro-zone (0.6747). It also shows a more favourable overall assessment of the Euro-zone countries that their starting interest rate $(0.2429)$ was lower than in the group of counties using their national currencies (0.5129), which is equivalent to a 0.15 percentage point interest rate difference. All this means that in 2014 money markets considered membership in the Euro-zone as a factor mitigating sovereign risk, which meant some interest savings compared to the EU member states using their own currencies. With regard to the lower steepness of the regression function, this saving was more significant in the case of Euro-zone member states of relatively high sovereign risk. (We need to remind you that Greece and Cyprus were not included in the analysis.) We also carried out the test based on the 2016 data. The coefficients of determination again showed the best fit in the case of the logarithmic function. Having inserted the data in this type of function, we got the following functions: Euro-zone (2016): $Y_{E 16}=0.6029 \ln (X)+0.2136$. The countries using national currencies: $(2016): Y_{N 16}=0.7699 \ln (X)-0.1703$. The functions are shown in figures 7 and 8.

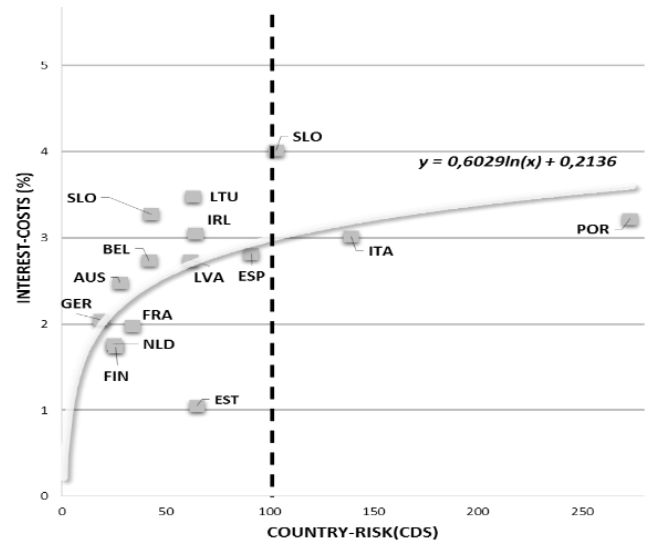

Figure 7 - Correlation between country (sovereign) and interest coverage in Euro-zone member states in 2016 (built by the author based on [13, 14])

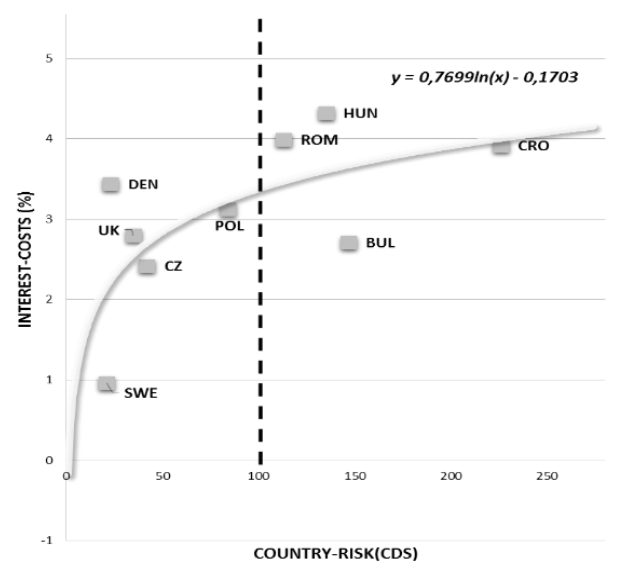

Figure 8-Correlation between country (sovereign) and interest coverage in EU member sta tes with national currency in 2016 (built by the author based on [13, 14]) 
Comparing the functions calculated based on the 2014 and the 2016 data we can ascertain that $Y_{E 16}$ became lower than $Y_{E 14}$, and in the same way $Y_{\mathrm{N} 16}$ became lower than $Y_{\mathrm{N} 14}$. This reflects the general decrease of interest rates. At the same time, the steepness of the functions changed in the opposite direction. The sovereign risk / interest cost function of 2016 in the Euro-zone is flatter than the one of 2014. The sovereign risk / interest cost function of 2016 however became steeper than the one of 2014 in the countries having their own currencies. The shitt is not significant, but it indicates a trend. It indicates that the significance of sovereign risk dropped within the Euro-zone and increased outside the Euro-zone.

The drop typical of the Euro-zone follows the theoretical assumption that sovereign risk should be lower in countries using the single currency especially if there are also common mechanism s protecting the solvency of the individual countries of the Zone. What actually ran opposite the theoretical assum ptions was that the global financial crisis largely increased sovereign risk and the interest rates of the bonds issued in Euro were largely different depending on the rating of the issuing Euro-zone country as stable or instable. The numbers show that due to the ceasing of financial turbulences and the introduction of the financial mechanisms in the EU, differences are becoming smaller. However, the pace is slow, and the differences are still significant, which is indicated by parameter 0.6029 of the logarithmic function.

What may explain the increase of the significance of sovereign risk in the interest cost trend of $E U$ member states having their own national currencies? The high liquidity of global financial markets should rather have introduced a reduction as in case of am ple liquidity even debtors with a higher risk can have access to credits more easily. (This correlation is made more complex by the segmentation of financial markets, for instance certain investment funds only purchase the safest rated financial instruments.) The demonstration of this effect however would demand a much deeper analysis. Exchange rate is another factor which may give an explanation for the differences. In the case of countries, having their own currencies, sovereign risk and exchange rate risk will shape interest costs together. The investors' forecast of the appreciation of the national currency will reduce the yield expectations of the bonds issued in own currency, and the assumption of depreciation will increase yield expectations. So the steeper sovereign risk / interest coverage function was probably the result of the exchange rate risk and the sovereign risk strengthening each other between 2014 and 2016: investors rather foresaw appreciation of own currencies in the case of countries with a low sovereign risk, while rather foresaw depreciation in the case of countries with a higher sovereign risk. This impact was strengthened - as an effect of exchange rate losses during the global crisis - by the fact that most countries increased the ratio of bonds issued in their own currencies, which increased the weight of exchange rate risks in the trend of interest costs. The role of exchange rate risk is indicated by the residue element of function $Y_{\mathrm{N} 16}$ becoming negative, which means that the initial interest rate became extremely low in countries with a low sovereign risk, which can be partially explained by the general expectation that the exchange rate risk will turn out positively.

In the case of both country groups, the analysis of the 2014 and 2016 data points to the fact that following the global economic crisis, sovereign risk can noticeably affect the cost of financing sovereign debt in a given country, i.e. the mitigation of the sovereign risk is in the financial interest of individual member-states. This is also true if at the current low level of interestrate, the cost increase due to higher sovereign risk is not material. If however financing conditions become less favourable, higher sovereign risk can again significantly drive up the cost of sovereign debt financing. The times before the global financial crisis will probably not come back when financiers considered the risk of state bankruptcy negligible in the case of developed countries.

The result of the analysis made with the data of the year of 2014 proved for both country groups that the correlation of sovereign risk and the cost per debt unit was relatively strong, but this did not fully 
explain the differences between the interest coverage ratios of the individual countries. In order to explore further causes of these differences, it is advisable to continue the analysis.

A possible reason for the differences is that the Eurostat data disclose the gross interest costs of debt management, which does not adjust interest costs with interest revenues although they decrease the actual costs of debt management. Interest revenues may come for instance from the interest and exchange rate gains if government bonds are repurchased before time, or from the interests of the deposits of temporarily available public liquidity. Based on other Eurostat statistics it can be found that in case of performance based accounting - the ratio of interest revenue to gross interest expenditure was between $3 \%$ and $20 \%$ in 2014 with the exception of one country, where interest revenues were extremely high. The 17-percentage point difference can partly explain the gross interest cost difference.

In our analysis, however we are examining another possible explanation. We are starting out from chart 6 . It shows that the interest cost ratios of some countries with typically similar sovereign risk are very different from one another. Such are for instance Sweden and Denmark, or Bulgaria and Hungary. We are assuming that the difference in the sovereign debt management strategies of the different countries is one of the possible reasons. In particular, there are countries pursuing a rather cost minimising strategy, whereas there are others having rather a risk minimizing strategy. This is made possible because there is a certain level of trade-off between the interest cost and the risk even in the case of sovereign debt financing. The manager of sovereign debt may choose - within limitations - to finance the sovereign debteither in a more risky way but more cheaply (on the shortterm), or rather in a risk avoiding way but more expensively. We have identified two factors where the existence of the tradeoff is obvious. One is bond issuance in foreign currency and the other is the maturity of bonds. If a debt manager issues bonds denominated in own currency for foreign investors, the exchange rate risk will be borne by the foreign investors therefore their expected interest on the bond will be higher than in cases when the bonds are denominated in a currency considered to be safer by the investors. (This correlation does notreally apply to the cases when the investors expect that the currency of the country issuing the bonds will be appreciated.) This correlation is clearly visible in terms of maturity; the longer the maturity of the bond, the higher interest trend will be achieved. Still, it may be in the sovereign debt manager's interest to increase the average maturity of the bonds as in this way the so-called renewal risk of the bonds (and also its costs) will be mitigated.

Consequently, in the case of a cost minimizing debt management strategy the proportion of bonds denominated in foreign currency is higher, and the average maturity of the bonds is lower than in the case of a risk minimising debt management strategy. There is however another noteworthy factor, the sovereign debt to GDP ratio as it significantly influences the debt manager's risk bearing ability. For the higher the sovereign debt ratio, the higher the cost to GDP ratio associated with a potential risk. For exam ple, if a country keeps 20 percent of its sovereign debtin foreign currency denominated bonds, and its sovereign debt ratio is 80 percent, then an amount of bonds representing 16 percent of the GDP is exposed to exchange rate risk. If the sovereign debt ratio is only 30 percent, only an amount of the bonds representing 6 percent of GDP is exposed to exchange rate risk. Renewal of sovereign debt financing also represents a high risk for deeply indebted countries because newbonds representing 20 30 or even higher percent of GDP need to be issued year on year in order to redeem the expiring bonds. All this means thatcountries with a high level of sovereign debt are better off pursuing a risk minimising strategy even if the interest costs are higher. This is because risk depends on two factors: the probability of the occurrence of a risky event and the extent of the projected loss. The level of the latter one depends on the sovereign debt ratio of a given country. Consequently, an indebted country should undertake lower risk, which - if all other variables are constant - means that its interest coverage ratio will be higher than that of a less indebted country with the same sovereign risk.

Next, we will first take the annual data of Denmark and Sweden and then of Bulgaria and Hungary for 
2014, and examine whether the cost minimising or risk minimising nature of their debt management strategies could have played any role in having significantly differentinterest coverage ratios in spite of their almostidentical sovereign risk. The analysis will be rather interesting, as we will compare the data of two low sovereign risk EU member states in the case of Denmark and Sweden, and of two high sover eign risk EU member states in the case of Bulgaria and Hungary. (We could only choose countries, which have their own currencies as there is no exchange rate risk at the level of individual countries within the Euro-zone.)

Table 2 shows data on the three examined factors from Denmark and Sweden for 31. December 2014. Foreign exchange denominated debt means the share of government bonds denominated in foreign currency in the total sovereign debt portfolio. Moreover, average remaining maturity means the average available time until the maturity of the issued bonds, where we can get the average by applying the weight of the bond value.

Table 2 - Main characteristics of sovereign debt in Denmark and Sweden (built by the author based on $[3,4,8,9]$ )

\begin{tabular}{|l|c|c|}
\hline Main characteristics of sovereign debt & Denmark & Sweden \\
\hline General government gross debt as a percentage of gross domestic product & 44,8 & 44,5 \\
\hline Sovereign debt denominated in foreign currency/ Total sovereign debt & 12,9 & 14,9 \\
\hline Average remaining maturity & 9,3 & 4,4 \\
\hline
\end{tabular}

The sovereign debt ratios of Denmark and Sweden in 2014 were at an identical low level in an EU comparison, which had a favourable impact on the risk of sovereign debt financing. Both countries could be characterized by a stable capital marketand a strong demand for securities, under which conditions funds were mainly invested in the local currency. The share of the foreign exchange denominated debt of the two countries was rather similar. Consequently, the difference of the interest coverage ratios could only be explained by the average time to maturity from the three examined factors.

As regards the average time to maturity ratio, Denmark's debtmanagement activity is characterized by a striving for the minimisation of longer-term risks. Denmark's strategy defined a weighted (with the relative value calculated at the present value of payments) average duration instead of the average time to maturity. The most im portant difference between the two indicators is that the average time to maturity is destined to primarily manage the liquidity risk of financing, while the weighted duration is rather destined to manage its interest risk.

The high duration goal in Denmark's sovereign debt management strategy serves the stability of debt financing on the one hand, and the long-term fixing of the interest rate at the time of issuance on the other hand. Because of the high duration level of the debt porffolio, the increase of interest rates can only be enforced within the system of financing on the horizon of many years therefore the strategy places the reduction of interest risk before short-term cost minimisation.

Contrary to the foregoing, Sweden's debt management strategy counts with the benefits of keeping the average remaining time to maturity at a low level in the current interest environment, while the recently experienced reduction in the long-term financing premium allows for a slight increase in the strategic goals to be achieved upon maturity.

This also shows that as far as the maturity of governmentbonds is concerned, Sweden is rather on the cost minimising side, while Denmark rather pursues a risk minimising debt management strategy. Due to the relatively low (but still considered to be safe) average duration of the term, Sweden could make better use of the global drop in interestcosts. Therefore part of the 1.7 percentage point difference in the average interest cost of financing (in 2014) can be actually explained by the fact that Sweden's debtmanagement strategy was primarily costm inimising, while Denmark's strategy was risk minimising. The above is nota value judgement of course as the savings of risk minimisation usually appear on the 
Г.3. Пулай. Ризик витрат на суверенний борг у державах-членах Європейського союзу як фактор розвитку їхньої економіки

longer term. The explored correlations however illustrate the point very clearly that the nature of a debt management strategy may have a serious impact on the trend of interest costs.

The values of the three examined indicators of Bulgaria and Hungary for 31 December 2014 are shown in Table 3.

Table 3 - Main characteristics of sovereign debt in Bulgaria and Hungary

(built by the author based on $[1,2,6,7]$ )

\begin{tabular}{|l|c|c|}
\hline Main characteristics of public debt & Bulgaria & Hungary \\
\hline Public debtGDP & 27,0 & 76,2 \\
\hline Public debt denominated in foreign Currency/Total public debt & 79,2 & 38,1 \\
\hline Average remaining maturity & 6,9 év & 4,5 év \\
\hline
\end{tabular}

All the three indicators are significantly differentbetween the two countries. The sovereign debt ratio of Hungary was almost three times the ratio of Bulgaria, which - in accordance with the above explanation meant that the Hungarian debt management strategy had a narrower space of manoeuvring, and it was more expedient to put the focus on risk minimisation. Due to the constraints of domestic demand in the securities markets, securities issued in foreign currency played a bigger role in the sovereign debt management financing of both countries than in the two Nordic countries. Their rates however were very different. Foreign exchange financing is at least twice as big in Bulgaria as in Hungary. This is also an explanation for the difference of interest costs as the government securities issued in EUR and USD in this period - assuming that all other factors were constant - had notably lower interest rates than the bonds issued in the national currencies. The fact that the foreign exchange risk had to be bome by the foreign investor represented only one reason for this. Another reason was that Hungary made a conscious effort to encourage the public to purchase government bonds, in the interest of which Hungary even undertook to introduce higher interests. Compared to this, the central bank of Bulgaria assumed the exchange rate risk of bonds issued in foreign currencies, thus encouraging the debt manager to issue foreign currency denominated bonds with lower interest rates. The difference between the interest costs of Bulgaria and Hungary can be also derived from the costor risk minimising nature of the debt management strategies but in the case of these two countries, the difference is reflected in the share of foreign exchange denominated debt. We need to point out here also that this finding is of a descriptive rather than of a qualifying nature as the actual occurrence of any foreign exchange risk may cause a severe loss for a country, which may run much higher than the savings realised based on a lower interest rate for many years.

The difference between the sovereign debt ratios of the two countries had an effect on the level of bearable risk. Because if we compare the value of foreign exchange denominated bonds to GDP, we find that the foreign exchange to GDP ratio of Bulgaria will be $21.4 \%$, while that of Hungary will be $29.0 \%$. These figures illustrate that Bulgaria had a larger playfield to undertake foreign exchange risk than Hungary, which was well advised to largely mitigate its foreign exchange risk.

There is also a significant difference in the average remaining maturity of the sovereign debts of the two countries. Based on this, we could think that as far as maturity is concerned, Hungary pursued a cost minimising, and Bulgaria a risk minimising strategy. The data however show the exact opposite of this. It can be explained by the fact that Bulgaria financed its sovereign debt mostly by long-term bonds issued in foreign currencies, while Hungary could not issue a large proportion of long-term government bonds on the retail securities market. This and not the conscious costminimising strategy can mostly explain that the average remaining maturity of Bulgaria's sovereign debt was 2.4 years longer than the ratio of Hungary.

Conclusions. Our analysis of the debt financing of EU member-states has revealed that in the wake 
of the 2008-2009 global financial crisis sovereign risk strongly affected the average cost of sovereign debt financing. This impact lingered after the crisis and still prevailed in 2016. Because of slackening interest rates, the cost driving effect of sovereign risk measurably decreased, but if interest rates pick up again, sovereign risk will significantly increase the sovereign debt financing costs of highly risky member-states. Consequently, it is in each EU country's serious material interest to reduce their sovereign risks. This is both true for the countries of the Euro-zone, and those having their own currencies.

The average costs of sovereign debt financing also significantly depend on whether the country pursues a cost or a risk minimising strategy in debt management. The savings reached by a cost minimising strategy can be notable on the short term. In spite of this, each country has to decide about the level of risk they are willing to take in their debt management. It is reasonable for member states with a high sovereign debt to GDP ratio to take lower risk even if this drives up the costs of financing their sovereign debts. Reducing the level of sovereign debt will be the safest way for them to reduce these costs.

Prospects for further research are primarily related to the development of methodological and practical support for the procedures for repaying sovereign debt. The conducted researches show that the problem of sovereign debts in the modern economy has ceased to be of national character and has reached the world level. Individual countries cannot cope with the repayment of public debt. It is also impossible to leave them alone to seek a way out of the crisis because of the growing interconnection of national economies. In this regard, itis extremely important to develop and adopt concerted measures to reduce sovereign debts to a safe level, which will contribute to the development of national and world economies.

1. Ministry of Finance ofthe Republic of Bulgaria (n.d.). GovernmentDebt. minfin.bg. Retrieved from http://www.minfin.bg/en/page/5

2. Ministry of Finance of the Republic of Bulgaria (2014). Debt Review. minfin.bg. Retrieved from http://www.minfin.bg/document/16941:2.

3. Danmarks Nationalbank (n.d.). Government Debt. nationalbanken.dk. Retrieved from http://www.nationalbanken.dk/en/governmentdebt/Pages/Default.aspx.

4. Danmarks Nationalbank (2014). Danish Government Borrowing and Debt nationalbanken.dk. Retrieved from http://www.nationalbanken.dk/en/publications/Pages/2015/02/Danish-Government Borrowing-and-Debt-2014.aspx.

5. Danmarks Nationalbank (2016). Danish Government Debt Management Policy. nationalbanken.dk. Retrieved from http://www. nationalbanken.dk/en/governmentdebt/publications/Documents/Strategy\%20announcement_2016.pdf.

6. Államadósság Kezelő Központ Zrt. [Central Government Gross Debt.] (n.d.). akk.hu. Retrieved from http://www.akk.hu/hu [in Hungary].

7. Államadósság Kezelő Központ Zrt. (2014). Éves jelentés az államadósság kezeléséről [Annual report on debt management]. akk.hu. Retrieved from http://www.akk.hu/uploads/qwGY2g7B.pdf [in Hungary].

8. Site of Riksgalden - Swedish National Debt Office. riksgalden.se. Retrieved from https://www.riksgalden.se/en/aboutsndo/.

9. Riksgalden - Swedish National Debt Office (2014). Basis for evaluation - Central Government debt management 2014. riksgalden.se. Retrieved from https://www.riksgalden.se/PageFiles/23863/basis-for-evaluation-central-government-debtmanagement-2014.pdf.

10. Riksgalden - Swedish National Debt Office (2016). Guidelines for central government debt management 2016. riksgalden.se. Retrieved from htps://www.riksgalden.se/PageFiles/23760/guidelines-for-management-of-central-government-debt-2016.pdf.

11. Aizenman, J., Hutchison M., \& Jinjarak, Y. (2013). What is the risk of European Sovereign Debt Defaults? Fiscal Space, CDS Spreads and Market Mispricing of Risk. Journal of International Money and Finance, 34(C), 37-59. DOI: 10.1016/j.jimonfin.2012.11.011.

12. S\&P Capital IQ (2014). Global Sovereign Debt: A market driven perspective (4th Quarter 2014). marketintelligence.spglobal.com. Retrieved from https://marketintelligence.spglobal.com/our-thinking/ideas/global-sovereign-debtreport-a-market-driven-perspective-4th-quarter-2014.

13. Eurostat (n.d.). Database. ec.europa.eu. Retrieved from http://ec.europa.eu/eurostat/data/database

14. Asset Macro (n.d.). CDS. assetmacro.com. Retrieved from https://www.assetmacro.com/?s=CDS.

15. A site of Eurostat. ec.europa.eu. Retrieved from http://ec.europa.eu/eurostat/st. 
Г.3. Пулай. Ризик витрат на суверенний борг у державах-членах Європейського союзу як фактор розвитку їхньої економіки

Г.3. Пулай, д-р екон. наук, доцент, директор з нагляду за проектом «Цілісність», директор Державного аудиторського бюро (Угорщина)

Ризик витрат на суверенний борг у державах-членах Європейського союзу як фактор розвитку їхньої економіки

Вартість фрінансування на одиницю суверенного боргу показує значну різницю в окремих державах-членах ЄС. Ця стаття намагається знайти пояснення для иього. Однією з причин автор досліджує феномен, що після фрінансової кризи суверенний ризик став фактором, який серйозно впливає на відсоткові ставки як у країнах єврозони, так і у країнах, що мають власні валюти. На середню процентну вартість також впливає вибір країн, щоб приділяти пріоритет мінімальним витратам або мінімізації ризиків у своїх стратегіях управління суверенними боргами.

Ключові слова: ризик, управління, суверенний борг, валюта, мінімізація витрат

Г.3. Пулай, д-р экон. наук, доцент, руководитель по надзору за реализацией проекта «Целостность», директор Государственного аудиторского бюро (Венгрия)

Риск затрат на суверенный долг в государствах-членах Европейского союза как фактор развития их экономики

Стоимость финансирования на единицу суверенного долга показывает значительную разницу в отдельных странах-членах EC. Эта статья пытается найти объяснение этого. В качестве одной из причин в нем рассматривается явление, которое в результате финансового кризиса суверенный риск стал фактором, серьезно влияющим на процентные ставки как в странах еврозоны, так и в странах, имеющих собственные валюты. Средняя процентная стоимость также зависит от выбора стран, чтобы отдать приоритет минимизации затрат или минимума в стратегиях управления суверенным долгом.

Ключевые слова: риск, управление, суверенный долг, валюта, минимизация затрат

Отримано 21.05.2017 p. 